\title{
Tilsvar til Olweus
}

\author{
Av RAGNAR HAUGE
}

Jeg finner ingen grunn til å gå nærmere inn på Olweus' mer generelle kommentarer til min artikkel. Vi er dypt uenige både når det gjelder opplegget av unders $\varnothing$ kelsen, bruken av stokastisk statistikk på et materiale som dette, de konklusjoner som trekkes og de konsekvenser som utledes av resultatene. Hvor og hvorfor vi er uenige skulle det ikke være n $\varnothing$ dvendig å utdype nærmere. Og mulighetene for å diskutere seg frem til enighet er åpenbart meget små.

Imidlertid hevder Olweus at jeg til dels gir en direkte feilaktig fremstilling av hans arbeid - og nevner fem eksempler på dette. Selv om disse punktene er svært perifere i min kritikk, vil jeg likevel imøtegå dem - fordi det ellers kan tolkes som uredeligheter i min fremstilling av Olweus' bok.

1. Jeg har i min artikkel etterlyst data om hvor mange av elevene som if $\phi$ lge klasseforstanderne av og til bed $\phi$ mmes som „hakkekyllinger" og av og til som ,skolebøller". Olweus hevder at opplysninger om dette finnes på s. 68. Der gis imidlertid ikke noe svar på spørsmålet. Det opplyses riktignok at knapt $10 \%$ av en eller annen lærer (min uthevelse) ble bed $\phi \mathrm{mt}$ som såkalte vekslere - men om denne prosentsatsen gjelder for klasseforstanderne sies det intet om.

2. Jeg hevdet også at det ville være naturlig å sammenlikne klasseforstandernes utpeking av elevene i henholdsvis 6. og 7 . årskurs, for å se på sammenhengen mellom dem isolert sett. Olweus' svar er at dette har han gjort på s. 57 - og at dette viser en sammenheng på $\chi^{2}=140.27$ - eller $82 \%$. Det jeg etterlyser or imidlertid tallverdiene. Statistiske angivelser av den art som Olweus opererer med, sier — som jeg har vist i min artikkel -. svært lite om eventuelle sammenhenger, bortsett fra at lærere sjelden karakteriserer elever hverken som ,hakkekyllinger“" eller

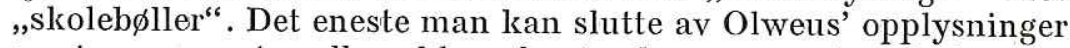
er at samsvaret mellom klasseforstanderne er enda mindre enn når man fritt velger hvilke læreres bedømmelse man vil legge til grunn.

3. Jeg etterlyste også opplysninger som kan gi grunn til å belyse samsvaret mellom kameratbed $\varnothing$ mmerne. Olweus henviser til at han på s. 39 gir referanser til ting han har skrevet tidligere og på s. 82 oppgir at reliabiliteten ofte (min uthevelse) er funnet å være $0.75-0.95$. Jeg har vanskelig for å godta at dette er noe svar på mitt spфrsmål. Ikke bare fordi det er en nokså svevende 
angivelse - men f $\phi$ rst og fremst fordi disse koeffisientene ikke stammer fra den foreliggende unders $\varnothing$ kelse, men fra andre unders $\varnothing$ kelser som Olweus har foretatt med samme metode.

4. Olweus hevder videre at jeg tar feil når jeg påstår at han i regelen ikke sier noe om det er ,hakkekyllingene“, ,skoleb $\phi 1$ lene“ eller de „veltilpassede“ elevene som skiller seg ut gjennom de svar de gir. Og han anbefaler meg å lese boken bedre. Jeg har fulgt hans råd - og kan medgi at uttrykket ,, regelen“ kanskje er for sterkt. La meg derfor endre min kritikk fra at han ,i regelen“ til ,,i en del tilfelle“ ikke sier noe om hvem det er som skiller seg ut.

5. Olweus hevder til slutt at jeg gir en uriktig fremstilling av det antall påstander som skiller mellom de tre grupper av elever. Som nevnt i min artikkel er det ikke så helt lett å få noe klart bilde av hva Olweus har funnet på basis av den beskrivelse han gir - men selv etter fornyet gjennomlesning kan jeg ikke se at min fremstilling skulle være uriktig.

\section{Kommentar till Hauges svar}

\section{Av DAN OLWEUS}

Av tidsskäl har jag tyvärr inte möjlighet att påvisa oredligheten i Hauges argumentering när han svarar på min kritik av hans artikel. Jag kan här bara uppmana läsarna att själv kontrollera vad som skrivits i de olika artiklarna och i min bok. Det är uppenbart - både med utgångspunkt från Hauges första artikel och hans svar — att han är helt ointresserad av de faktiska sakförhållandena och dessutom beredd att använda nästan vilka medel som helst för att försöka nå sina syften. 